\title{
Calcite production by coccolithophores in the south east Pacific Ocean
}

\author{
L. Beaufort ${ }^{1}$, M. Couapel ${ }^{1}$, N. Buchet ${ }^{1}$, H. Claustre ${ }^{2}$, and C. Goyet ${ }^{3}$ \\ ${ }^{1}$ CEREGE, Aix-Marseille Université - CNRS, BP80 cedex4, 13545 Aix en Provence, France \\ ${ }^{2}$ CNRS, Laboratoire d'océanographie de Villefranche, 06230 Villefranche-sur-Mer, France; Université Pierre et Marie \\ Curie-Paris 6, Laboratoire d'océanographie de Villefranche, 06230 Villefranche-sur-Mer, France \\ ${ }^{3}$ Université de Perpignan, 52, Avenue Paul Alduy, 66860 Perpignan, France
}

Received: 5 September 2007 - Published in Biogeosciences Discuss.: 17 Sptember 2007

Revised: 10 June 2008 - Accepted: 3 July 2008 - Published: 4 August 2008

\begin{abstract}
BIOSOPE cruise covered an oceanographic transect through the centre of the South Pacific Gyre (SPG) from the Marquesas archipelago to the Peru-Chile upwelling (PCU). Water samples from 6 depths in the euphotic zone were collected at 20 stations. The concentrations of suspended calcite particles, coccolithophores cells and detached coccoliths were estimated together with size and weight using an automatic polarizing microscope, a digital camera, and a collection of softwares performing morphometry and pattern recognition. Some of these softwares are new and described here for the first time. The coccolithophores standing stocks were usually low and reached maxima west of the PCU. The coccoliths of Emiliania huxleyi, Gephyrocapsa spp. and Crenalithus spp. (Order Isochrysidales) represented more than $30 \%$ of all the suspended calcite particles detected in the size range $0.1-46 \mu \mathrm{m}$ ( $22 \%$ of PIC in term of calcite weight). These species grew preferentially in the Chlorophyll maximum zone. In the SPG their maximum cell concentrations were recorded between depth of 150 and $200 \mathrm{~m}$, which is unusually deep for these taxa. The weight of coccoliths and coccospheres were correlated to their size. Large and heavy coccoliths and coccospheres were found in regions with relatively high fertility in the Marquises Island and in the PCU. Small and light coccoliths and coccospheres were found west of the PCU. This distribution is strongly related to ocean chemistry in particular to alkalinity and to carbonate ions concentration. The biotic (coccolithophores production) influence on calcification is mainly driven at the local scale (depth) whereas the abiotic (carbonate chemistry) plays its most important role at the regional (horizontal) level. Here $94 \%$ of the variability of coccolith and coccosphere weight can be explained by a change in 7 environmental variables.
\end{abstract}

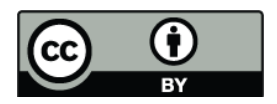

Correspondence to: L. Beaufort (beaufort@cerege.fr)

\section{Introduction}

Coccolithophores represent an important group of unicellular algae. They are abundant both at high latitudes, where they form large blooms detectable by satellites (Brown and Yoder, 1994; Balch et al., 2007), and at low latitudes in oligotrophic (e.g. Okada and McIntyre, 1979; Winter et al., 1994) and upwelling (e.g. Winter et al., 1994; Giraudeau and Bailley, 1995) areas. They are responsible for about half of the total oceanic carbonate production (Milliman, 1993). Carbonate precipitation, settling (including ballasting aggregates containing organic mater), burial, and dissolution are key processes of the oceanic carbon cycle (e.g. Archer et al., 2000). Yet, despite their major role in the $\mathrm{CO}_{2}$ cycle, many aspects of calcite production by coccolithophores are not well constrained. In particular the environmental impact on the secretion of coccoliths are poorly understood because direct field observations are scarce (Balch and Kilpatrick, 1996). Several laboratory and mesocosms experiments have shown a decrease in the production of calcium carbonate by coccolithophores when atmospheric $\mathrm{CO}_{2}$ increases (e.g. Riebesell et al., 2000; Engel et al., 2005). This is because an increase of $\mathrm{CO}_{2}$ in the atmosphere causes a decrease of oceanic water $\mathrm{pH}$, with potentially dramatic consequences for oceanic calcifiers (Feely et al., 2004; Orr et al., 2005). It is therefore critical to determine how coccolithophores are calcifying in today's Ocean.

The South Pacific Gyre (SPG) is the most oligotrophic and one of the least sampled ocean areas (Claustre and Maritorena, 2003), particular for coccolithophores. The primary objective of BIOSOPE (BIogeochemistry and Optics South Pacific Experiment) was to study the South Pacific Gyre along a transect through the central part of the SPG to the Peru-Chile Upwelling (PCU). The Isochrysidales represent, numerically, the most important order of coccolithophores. We document, along this transect, variations of

Published by Copernicus Publications on behalf of the European Geosciences Union. 


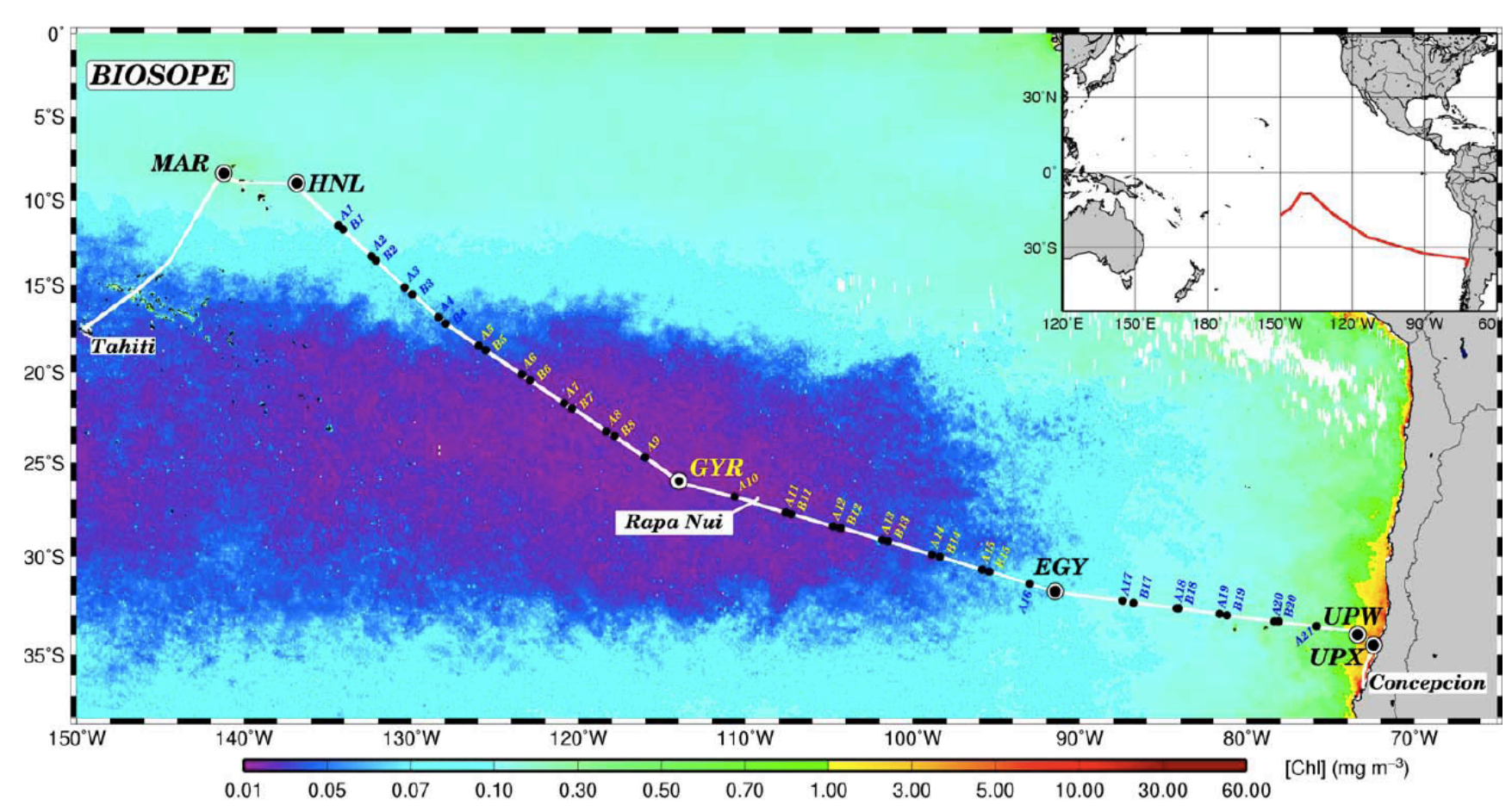

Fig. 1. Location map showing the transect and stations where water samples were taken at 6 depths, superimposed on the SeaWiFS composite (November-December 2004) for surface Chlorophyll concentration. Inset: geographic location of the transect in the Pacific Ocean.

Isochrysidales standing stock, as well as the absolute abundance of detached coccoliths and other small suspended calcite particles. The calcite stock produced by Isochrysidales was estimated using recently developed methods based both on microscopy automation and the birefringence properties of calcite. The size and weight of the coccospheres and coccoliths, was investigated in order to describe how Isochrysidales were calcifying in contrasting natural trophic environments, in particular in relation to calcite saturation state.

\section{1-Material and methods}

\subsection{Setting}

The BIOSOPE cruise (26 October to 11 December 2004) was conducted on board RV Atalante and covered a transect of about $8000 \mathrm{~km}$ in the South East Pacific. This enabled us to sample a full oceanic spectrum from the most oligotrophic oceanic waters in the south Pacific gyre to the fertile coastal waters of Chile (Fig. 1). Two features may explain why the broad South Pacific Gyre possesses the lowest surface chlorophyll concentration estimated through satellite imagery $\left(0.019 \mathrm{mg} \mathrm{Chl}-a \mathrm{~m}^{-3}\right)$. It has the largest pycnocline depth recorded in the world ocean hydrological database ( $>200 \mathrm{~m}$ ), and the flux of atmospheric dust (e.g., iron) is extremely low (Claustre et al., 2008). In contrast, the PCU sys- tem and the Marquesas archipelago (sub-equatorial area) are bathed by nutrient richer waters.

The sea surface temperature and salinity recorded during the cruise varied between $13^{\circ}$ and $28^{\circ} \mathrm{C}$ and from 34 to 36.5 , respectively, with higher values toward the west and lower values toward the east.

\subsection{Sampling}

Twenty stations were sampled for biogeochemical parameters (Claustre et al., 2008). At every station, samples for coccolithophores were taken depending on the position of the Deep Chlorophyll Maximum (DCM). At most stations, water samples were taken at 6 water depths: one sample at $5 \mathrm{~m}$ (i.e., just below the surface), two samples between $5 \mathrm{~m}$ and the DCM, one sample at the DCM, and two samples below the DCM. The DCM is located near the pycnoline which is considered as one of most important ecological boundaries in the ocean (Longhurst, 1998). The sampling strategy thus enabled us to study coccolithophores above and below this significant ecotone. In most cases, four liters of seawater were filtered on a nitrate cellulose membrane $(47 \mathrm{~mm}$ diameter) having a pore size of $0.45 \mu \mathrm{m}$. The membranes were quickly dried and stored at room temperature. Once in the laboratory, a quarter of each membrane was mounted between slide and cover slip and fixed with Canada balsam, which rendered the 
membrane optically transparent. Additionally a small fragment of the filter was examined using a Hitachi 3000N Scanning Electron Microscope (SEM).

At the last four stations of the transect (i.e. in the PCU) the filter membrane diameter was $23 \mathrm{~mm}$. Four liters of water were still filtered so the amount of particles on these filters was extremely high, leading to the possibility that significant amounts of coccoliths were concealed by large particles. Thus absolute abundances could not be reliably estimated for these stations.

\subsection{Coccolithophore determination and species counts}

The composition of the coccolithophore assemblages was determined using SEM at magnification of about 6000x and a Polarizing Microscope (PM) Zeiss Axioscop at a magnification of 1000x. Species abundances were estimated by counting more than 300 coccospheres in counted field of views ( 70 on average). The number of field of view was never lower than 10 even when coccolithophores were abundant on the PM.

\subsection{Grabbing frames}

A Polarizing Microscope (LEICA DMRBE) with a 50X oil immersion objective was used for automatic scanning of the microscope preparations in cross-polarized light. Microscope stage motions and focus were automated. For each sample, a 2 Megapixel Spot Insight camera grabbed forty fields of view. Each frame is $240 \times 180 \mu \mathrm{m}^{2}$ with a pixel area of $0.0225 \mu \mathrm{m}^{2}$. The amount of light going through the sample was held constant.

\subsection{Analyzing calcite particles:}

We developed a new software using routine LabView (National Instruments) that automatically detects and measures all birefringent particles from grabbed frames, hereafter called "Particle Analyser". It takes advantage of the fact that some crystals are birefringent (they are illuminated in cross-polarized light) whereas other crystals and the preparation background remain dark. There is a relation between the thickness and the brightness of crystals, which can after calibration be expressed as a transfer function (Beaufort, 2005). The Particle Analyser opens all the frames in a sample, counts the number of objects brighter than background, and measures their surface. We placed a lower threshold at 3 pixels $\left(0.07 \mu \mathrm{m}^{2}\right)$ to get rid off background noise; and set an upper threshold at 74000 pixels $\left(1683 \mu \mathrm{m}^{2}\right.$ equivalent to circular particles having a $46 \mu \mathrm{m}$ diameter; e.g., a foraminifera). This upper-threshold is high enough to include all particles in the size range of nannoplankton, including aggregates. The number $(\mathrm{N})$ of particles $\mathrm{ml}^{-1}$ is calculated by

$N=N t \cdot S m /(N f \cdot S f \cdot V f)$

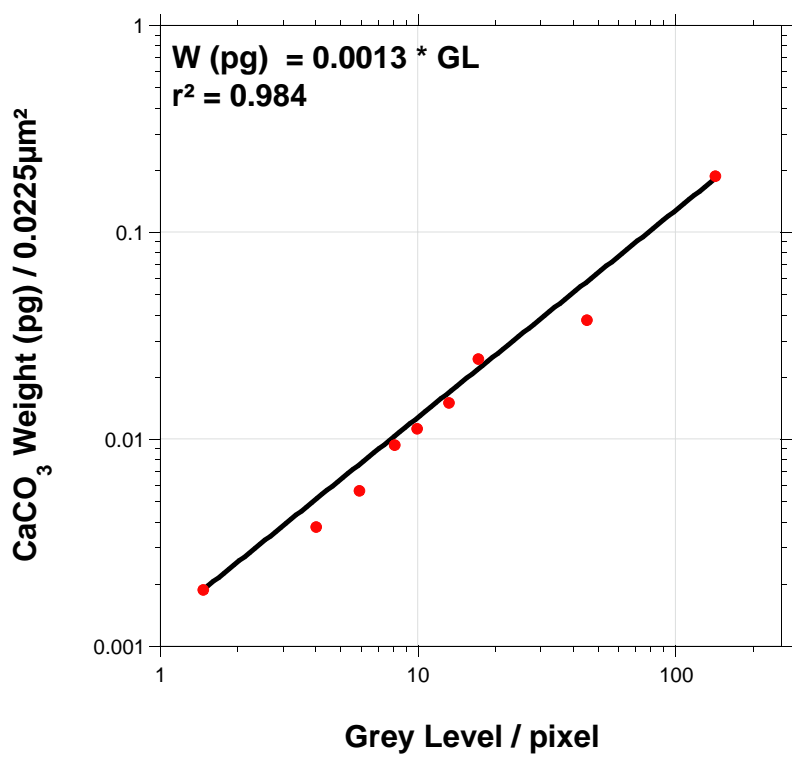

Fig. 2. Transfer function of Grey Levels into calcite weight. The $\mathrm{x}$-axis represents the Grey Level value measure on average of one pixel. The y-axis gives the calcite weight (in pg) put onto the membrane per surface unit (here the area of one pixel). The line represents the best regression going through the origin.

where $V f$ is the volume filtered in milliliter, $S m$ is the surface area of the membrane, $N f$ is the number of the grabbed frames, $S f$ is the surface area of the grabbed frames, and $N t$ is the total number of particles analysed per sample.

The Particle Analyser automatically measures the "lightness" $(L)$ of all frames as the sum of all grey levels $(G L)$ pixel values. A transfer function was established following the protocol established in (Beaufort, 2005), but applied to samples prepared with cellulosic membranes instead of smear slides. In recalibrating we poured different (precisely weighted) amounts of pure calcite powder into known volumes of water. These suspensions were filtered on membranes of the same type as used for the BIOSOPE samples, and processed as described above. The relation between $G L$ and weight on the membrane now serves as a transfer function (Fig. 2).

$w=0.0013 \cdot G L$

where $w$ is the weight in pg per pixel $\left(0.0225 \mu \mathrm{m}^{2}\right)$.

The calcite weight $\mathrm{ml}^{-1}(W)$ is calculated as following:

$W=w \cdot N p \cdot S m /(N f \cdot S f \cdot V f)$

Where $N p$ is the number of pixel per frame $\left(=210^{6}\right)$. The values are given in $\mathrm{pg} \mathrm{ml}^{-1}$. Particulate Inorganic Carbon (PIC) is often given in $\mathrm{mmol} \mathrm{CaCO}_{3} \mathrm{~m}^{-3}$. PIC values for the fraction $<46 \mu \mathrm{m}\left(\mathrm{PIC}_{<46 \mu}\right)$ in this unit are obtained by dividing $W$ by $10^{5}$. 
Four different sources of error may be associated with this method:

1. The main source of error results from the patchiness of the distribution of particles on the membrane. Only a portion of the membrane is measured.

2. The error on the estimate of the light measure is extremely small and considered negligible.

3. High sediment loads on the membrane produce particle aggregation and is a potential source of error (underestimation of the weight) but for the open ocean waters investigated during BIOSOPE this problem did not occur.

4. Focus may be the cause of a small error on absolute values. Frames out of focus were excluded from the analysis.

The overall error associated with this method when dealing with carbonated sediments is estimated at $\sim 12 \%$ (Beaufort, 2005), although no estimate regarding the measurments of PIC from water samples is available as yet.

2.6 Automated analysis of coccoliths and coccospheres: taxonomic recognition and size analysis

Coccoliths and coccospheres were automatically detected by SYRACO, a software developed in C++ at CEREGE (Dollfus and Beaufort, 1999; Beaufort and Dollfus, 2004). Based on Artificial Neural Networks (ANN) SYRACO is adapted to pattern recognition. In this study the ANN has been trained by the SYRACO learning algorithm, on a training set composed of two classes: (1) elliptical placoliths (essentially Emiliania huxleyi, Gephyrocapsa oceanica and other small placoliths in the genus Gephyrocapsa and Crenalithus; or Reticulofenestra for some authors), and (2) spherical coccospheres smaller than $10 \mu \mathrm{m}$ in diameter bearing relatively birefringent, elliptical placoliths having a size of about $1 / 2$ to $1 / 4$ of the coccosphere. The great majority of taxa having these characteristics belongs to the Order of Isochrysidales. The training set is a monospecific sample from the Southern Indian Ocean with only coccospheres of E. huxleyi. However ANN has a large generalisation capability such that the coccosphere recognition used here is not species specific. Coccospheres from other orders (Syracosphaerales, Zygodiscales and Coccolithales) are generally not recognized by this ANN.

Because of the large generalisation capability of the ANN, a significant number of objects that resemble somewhat the targeted pattern are also included in the specific output frames. In the case of coccospheres, these foreign objects are "manually" erased from the frame. For the coccoliths, they are automatically eliminated from the analysis by a new software developed in LabView.
This software, hereafter called "Coccolith Analyser", automatically measures coccoliths and coccospheres. It reads output frames where all the objects recognized as coccoliths are stored and analyses all of them. "Coccoliths Analyser" is able to identify coccoliths based on 4 landmarks. If it determines that an object in the frame possesses these 4 landmarks, then it identifies it as a coccolith. If, on the contrary, it determines that an object does not possess these 4 landmarks, it discards the latter. With "Coccolith Analyser", all objects incorrectly identified as coccoliths by SYRACO are eliminated. In the case of coccospheres, all the objects that were incorrectly identified as coccospheres by SYRACO were erased manually with "Adobe Photoshop" from the frames (we haven't design yet a software capable to detect true coccosphere).

To check the reliability of SYRACO's in estimating the abundance of coccospheres of Isochrysidales species in our samples, we compared SYRACO's data with estimates based on direct counts of coccospheres using a polarizing microscope. We found that the two (automated and manual) estimates are highly correlated $(R=0.95)$ (Fig. 3a). A slope of 2.2 could be interpreted as indicative that SYRACO misses about half of the coccospheres, but this is not the case. This slope reflects the fact that only few samples were taken at 4 stations (STB15 to STB18) located between 90 and $100^{\circ} \mathrm{W}$ an area where E. huxleyi coccospheres are extremely abundant and often contiguous. SYRACO is not capable of deciphering coccospheres in such groups. If the results from these 4 stations are excluded, the slope of the regression line is 0.98 , indicating that the number of coccospheres of Isochrysidales species recognized by SYRACO is the same as recognized by direct human counts. Incidentally, this excellent fit confirms that only Isochrysidales are recognized by SYRACO (the slope is 1.75 when the entire (including not only the Isochrysidales but all the taxa) coccolithophore assemblage counted by human is used for comparison with SYRACO counts) (Fig. 3b). We estimated the abundance of coccoliths by directly counting the number of coccoliths contained in more than 10 fields of view $\left(=0.01 \mathrm{~mm}^{2}\right)$ in a total of 36 samples. Our estimates were then compared with those obtained by SYRACO. The estimates of coccolith abundance are significantly correlated for all stations (except STB15 to STB18), with a slope close to 1 and a $R>0.9$. For stations STB 15 to STB 18 the abundance of coccoliths was often $>800 \mathrm{ml}^{-1}$; aggregation of coccoliths prevents accurate counts of coccolith number in a frame by SYRACO. The abundance estimates reported in this paper are those determined by SYRACO for all samples except for those at Stations STB15 to STB18 for which manual counts were established. Our preference for SYRACO counts is that they are more representative of real values, counts being produced over a much larger area than is possible by humans. SYRACO counts are also more reproducible than human's counts. It is important to note, however, that the patterns observed in BIOSOPE are the same whether established solely 

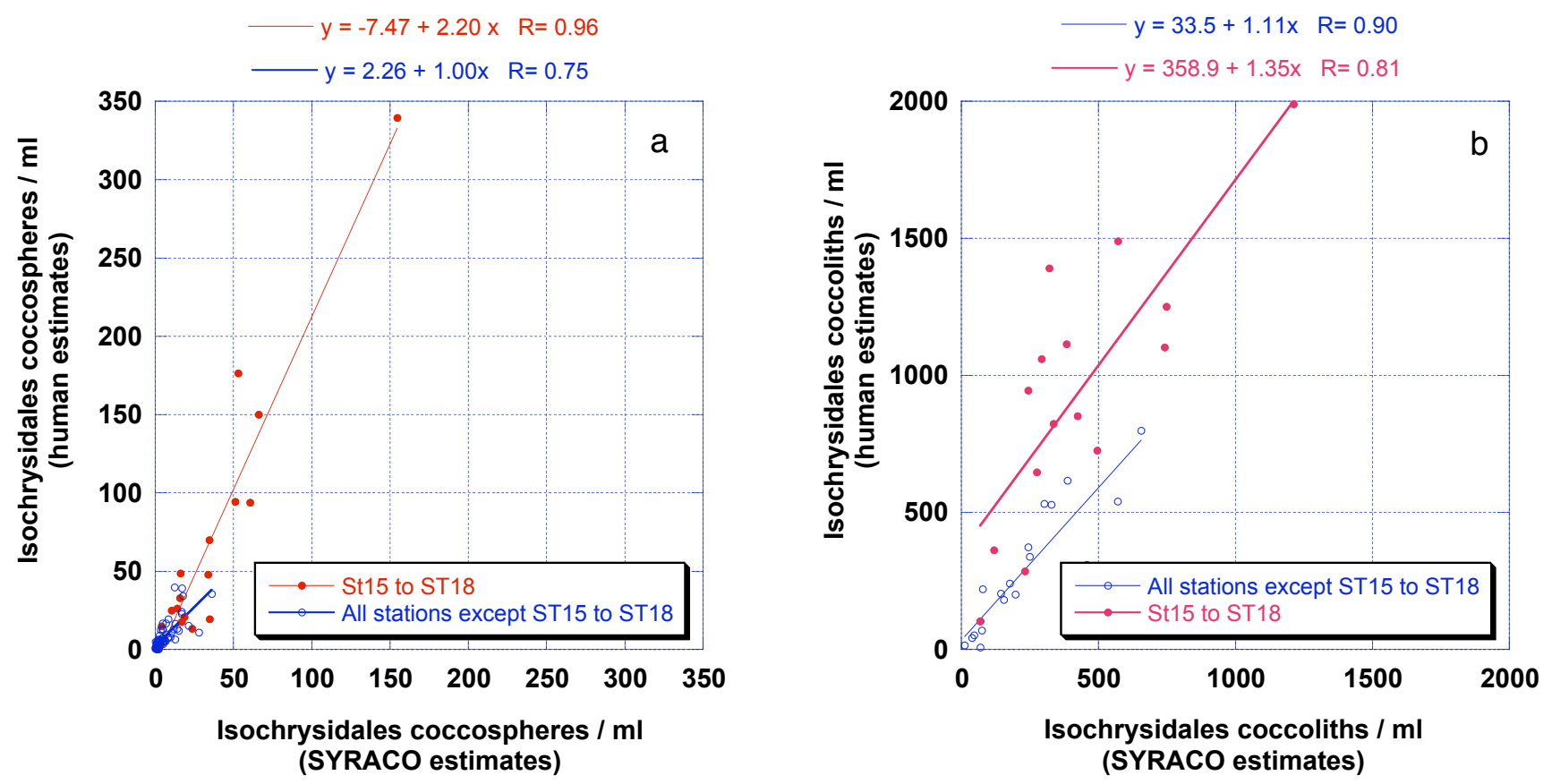

Fig. 3. Relation between "human" and "automated" (SYRACO) counts of Isochrysidales coccospheres (A) and coccoliths (B). In red are sample for 4 stations (STB15 to 18) where the density of Isochrysidales was too high (aggregation) for accurate automatic estimates. In blue are reported the other BIOSOPE stations.

from manual or automatic processes.

The Coccolith Analyser measures the grey level of objects, their diameter and surface, and tabulates the results. There is a bias of $0.6 \mu \mathrm{m}$ in the measurement of the diameter of small, and dim objects, such as coccoliths. This is because we apply a minimum Grey Level threshold above background. This threshold erodes 2 pixels of the periphery of dim objects. Each pixel is $0.15 \mu \mathrm{m}$, and 4 pixels are eroded in total when the long diameter is measured. Thus we added $0.6 \mu \mathrm{m}$ to the measurement of coccolith length to compensate for this automatic loss. Another small bias in the measurements of the length of coccoliths of $E$. huxleyi exists, the distal shield being not detected in its entirety in cross-polarized light. Therefore the length of E. huxleyi presented here are slightly underestimated. We estimated this bias to a factor of 1.25 by comparing measures from the Coccolith analyzer and from SEM. The data presented here are uncorrected by this factor.

It should be noted that in the theoretical case of a pure $E$. huxleyi sample, the size distribution estimated by SYRACO would be narrower that that estimated with the Calcite Analyser. This is because SYRACO detects only well preserved, well-oriented and isolated coccoliths whereas the Calcite Analyser measures all particles, including aggregated, broken, out of focus and tilted coccoliths.

\subsection{Chemical and physical parameters}

The physical and chemical parameters used for comparison here were measured in situ during the cruise and are described in different papers in this volume. Temperature, salinity, fluorescence (Claustre et al., 2008) and backscattering (Twardowski et al., 2007) were measured precisely at location where water was collected for coccolithophores. Carbon chemistry was measured (Azouzi et al., 2007) at nearby locations but not exactly at the same water depth. We have selected the measurements available from the closest depths.

\section{Results}

\subsection{Importance and composition of the Isochrysidales}

Emiliania huxleyi and several species of the genera Gephyrocapsa and Crenalithus represent all the calcifying taxa of the marine Order Isochrysidales (de Vargas et al., 2007). SYRACO has been trained to recognize the Isochrysidales complex, which is therefore the focus of this paper. The specific composition of Isochrysidales varied significantly among BIOSOPE samples. Their variations have been studied in detail with both SEM and PM. East of Easter Island (about $110^{\circ} \mathrm{W}$ ) the Isochrysidales dominated the coccolithophore community with relative abundance ranging from 60 to $100 \%$. West of Easter Island the coccolithophore concentration diminished with the Isochrysidales representing 


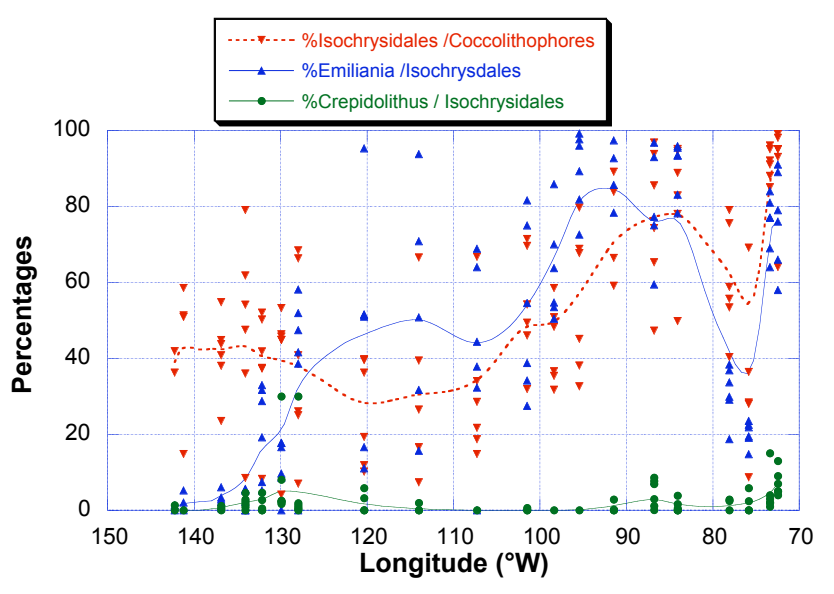

Fig. 4. Variations in the relative abundance of several coccolithophores taxa along the BIOSOPE transect. The data result from manual counts of coccospheres on the light microscope. The percentages of Isochrysidales in the coccolithophores are in red, the percentages of E. huxleyi in the Isochrysidales are in blue and the Crepidolithus (Reticulofenestra for some authors) are in green. The dots represent samples and the smooth lines show the stations means of these percentages.

$40 \%$ on average of the coccolithophore community (Fig. 4). Gephyrocapsa oceanica dominated the Marquesas area. Between $130^{\circ} \mathrm{W}$ and $100^{\circ} \mathrm{W}$ the relative abundances of Gephyrocapsa and Emiliania were variable with a low number of Emiliania. From $100^{\circ} \mathrm{W}$ to the PCU, Emiliania dominated the communities. In some samples it constituted almost $100 \%$ of the coccolithophores. Gephyrocapsa ericsonii and Crenalithus always formed a minor part of the coccolithophore assemblages.

Because the version of SYRACO used in this study was trained to recognize only the coccoliths of the Order Isochrysidales, we relied on manual estimates for: 1) the percentages of the Isochrysidales coccospheres in the coccolithophores assemblages, and 2) the percentage of the various species in the Isochrysidales assemblages. To estimate the number of detached coccoliths of the different taxa, we combined the number of Isochrysidales coccoliths with our estimate of the coccolithophores taxonomic composition produced manually. Our first order assumption is that the number of detached coccoliths per coccosphere is the same in every species (which is not necessarily the case).

\subsection{Spatial distribution of calcite particles}

The concentrations of suspended calcite particles, and of detached coccoliths and coccospheres of the Isochrysidales Order showed very similar distribution patterns along the BIOSOPE transect (Fig. 5): maximum concentrations were found between $80^{\circ}$ and $100^{\circ} \mathrm{W}$, associated with the subtropical front (Claustre et al., 2008)
The concentration in coccospheres of Isochrysidales was generally low with an average of $11 \mathrm{ml}^{-1}$ but it reached a maximum of $350 \mathrm{ml}^{-1}$ in the eastern part of the transect, while the concentration of detached coccoliths ranged from 11 to $\sim 2000 \mathrm{ml}^{-1}$ with an average of 250 . The concentration in suspended calcite particles was on average $733 \mathrm{ml}^{-1}$, and the total weight of calcite per milliliter was $11200 \mathrm{pg} \mathrm{ml}^{-1}$

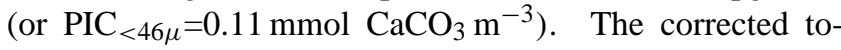
tal weight of the Isochrysidales detached coccoliths and coccospheres was on average $2224 \mathrm{pgml}^{-1}$ (or $0.022 \mathrm{mmol}$ $\mathrm{CaCO}_{3} \mathrm{~m}^{-3}$ ), which represents $22 \%$ of the $\mathrm{PIC}_{<46 \mu}$. Large aggregates that may be rich in coccoliths composed a large part of remaining $78 \%$.

The spatial distributions of coccospheres, detached coccoliths, and suspended calcite particles showed higher concentrations between $85^{\circ} \mathrm{W}$ and $100^{\circ} \mathrm{W}$ in the upper $80 \mathrm{~m}$ of the water column.

The observed pattern of density distribution of calcite particles is confirmed by the study of backscattering properties (Twardowski et al., 2007). The backscattering ratio (i.e. the ratio of backscattering to scattering) depends on the size distribution of particle assemblages (high when dominated by small particles and reciprocally) and on refractive index (high for particles with high refractive index, like calcite). This ratio approximately scales with the number of suspended calcite particles and the PIC estimated by the "Calcite Analyser" more specifically, it exhibits the two prominent scatters of coccoliths at the exact same position than shown in the present analysis, and confirms the relative "patchy" distribution of these biogenic particles.

3.3 Grain size distribution of suspended calcite particles, detached coccoliths and coccospheres

Ninety five percent of the 416000 suspended calcite particles analyzed from the BIOSOPE samples had a surface area $<20 \mu \mathrm{m}^{2}$ or a diameter $<5 \mu \mathrm{m}$ (in the $0.1-46 \mu \mathrm{m}$ range). Their size distribution was unimodal and slightly skewed toward larger particles, with a mode at $3.2 \mu \mathrm{m}^{2}$ (Fig. 6a). The distributions of detached coccoliths and coccospheres was also unimodals with modes at $3.2 \mu \mathrm{m}^{2}$ and $40 \mu \mathrm{m}^{2}$, respectively (Fig. 6a). Interestingly, the mode of the suspended calcite particles was the same as that of the detached coccoliths of Isochrysidales species. The number of detached coccoliths (mostly E. huxleyi, a few Gephyrocapsa and rare Crenalithus) represented $1 / 3$ of all suspended calcite particles. At locations where coccoliths and coccospheres were extremely abundant, for instance at $30 \mathrm{~m}$ at Station 18 which corresponded to an almost monospecific bloom of $E$. huxleyi, the distribution of calcite particles and of coccoliths/coccospheres were very similar (Fig. 6b).

The concentrations of coccoliths are significantly correlated with the concentrations of calcite particles detected by the Calcite Analyser (Fig. 7). The Isochrysidales taxa, and in particular E. huxleyi, are the most important contributor 

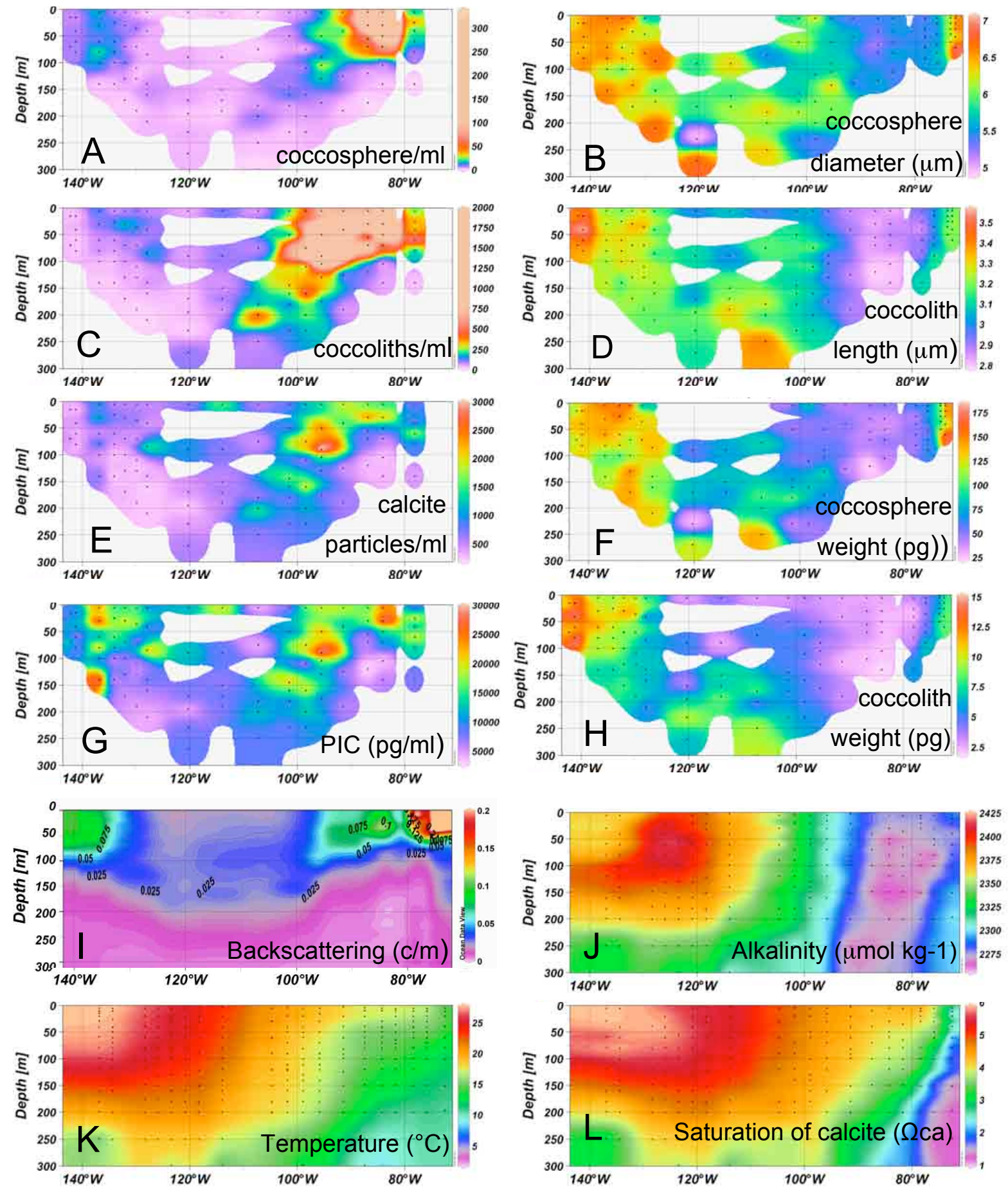

Fig. 5. Section along the BIOSOPE transect of (A) concentration in Isochrysidales coccospheres; (B) length of detached Isochrysidales coccoliths $(\mu \mathrm{m})$; (C) concentration of detached Isochrysidales coccoliths; (D) Average diameter of Isochrysidales coccospheres $(\mu \mathrm{m})$; (E); concentration in suspended calcite particles; (F) Average weight of detached Isochrysidales coccoliths (pg); (G) Total concentration of suspended calcite particles (PIC); (H) cocolith weight; (I) Attenuation coefficient (processed as described in Claustre et al., 2008) $\left(\mathrm{m}^{-1}\right.$ ); (J) Alkalinity $\left(\mu \mathrm{mol} \mathrm{kg}^{-1}\right)$; (K); In situ temperature $\left({ }^{\circ} \mathrm{C}\right)$; (L) Saturation of Calcite $(\Omega \mathrm{Ca})$. 

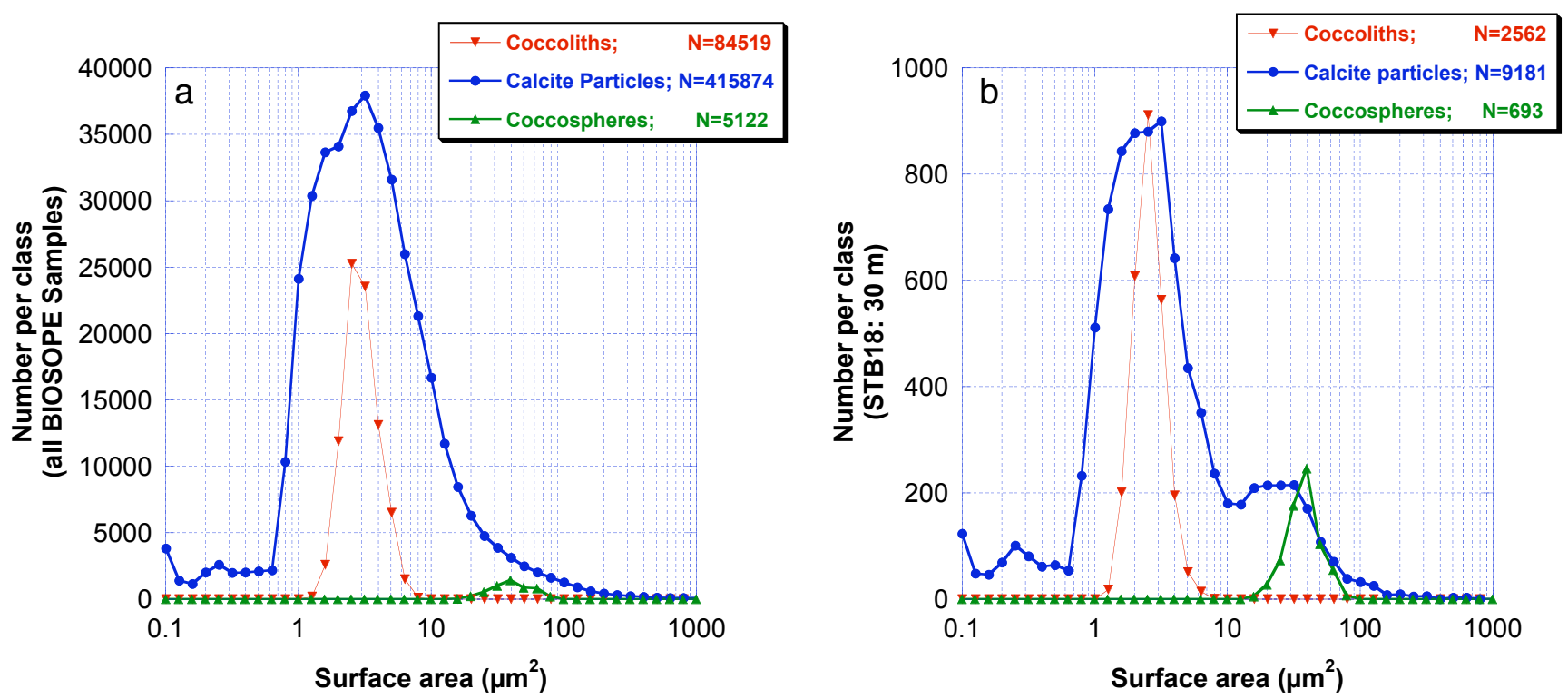

Fig. 6. Size Distribution of area of coccoliths (red), coccospheres (green) and calcite particles (blue) in all samples (A) and in sample taken at $30 \mathrm{~m}$ at Station $18(\mathbf{B})$.

to this correlation. The non-E. huxleyi Isochrysidales and the non-Isochrysidales coccolithophores were less correlated with the carbonate particle density (Fig. 7). Emiliania huxleyi dominated the assemblages where the coccolith density and calcite particles were the highest, demonstrating that $E$. huxleyi were a major source of fine suspended calcite particles in the open ocean.

\subsection{Size and weight distribution and number of coccoliths} per coccosphere

The diameter and weight of the coccoliths and coccospheres show the same spatial distribution (Fig. 5). In general, both had higher values in the western part of the transect, decreased progressively toward the east until they reached their minima around $90^{\circ} \mathrm{W}$, and slightly rose in the PCU (Fig. 8). There were significant correlations (Fig. 9) between the average length of coccoliths and the average diameter of coccospheres $(r=0.85)$. The same was true for their weights $(r=0.88)$. There were also significant correlations between the average of the weight and length of the coccoliths $(r=0.95)$ and diameter of the coccosphere $(r=0.94)$.

Assuming that the detached coccoliths have the same morphological characteristics as the attached coccoliths on the coccosphere, then the number of coccoliths per coccosphere was obtained by dividing the average weight of coccospheres by the average weight of the coccoliths. Doing so, we found an average of 15 coccoliths per coccospheres with standard deviation of 5. No clear pattern was found in the spatial distribution of that number.

\subsection{Depth profiles}

Morphometric and abundance data showed depth profiles which are similar to depth profiles of chlorophyll concentration. The maxima of abundance, weight, for both coccospheres and coccoliths were generally found associated with the chlorophyll maximum (Fig. 10). In consequence, the concentrations in coccolithophores and coccoliths, their weight and their size, were highest at shallow depth in the upwelling area, and deep in oligotrophic area. For example in the centre of the gyre, Isochrysidales taxa were most abundant between 150 and $200 \mathrm{~m}$.

\section{Discussion}

\subsection{Abundance distribution}

The coccosphere stocks estimated in the South East Pacific were low, with a median value of 4000 cell $^{-1}$. The lowest values were found at the centre of the South Pacific Gyre (GYR station). However in the centre of the gyre and at all stations, coccolithophores were continuously present down to the deepest sample $(200-300 \mathrm{~m})$ where sufficient light is remaining for the growth of some species (Claustre et al., 2008). The average Isochrysidales stock at Station GYR was 1250 cell per liter. This is equivalent to $375 \times 10^{6}$ cells m$^{-2}$ in a $300 \mathrm{~m}$ deep water column; this value represents only the stock of marine Isochrysidales which represent a small coccolithophore fraction (1/3). These data imply that coccolithophore are in abundance even in the extreme oligotrophic environments that we investigated. The 


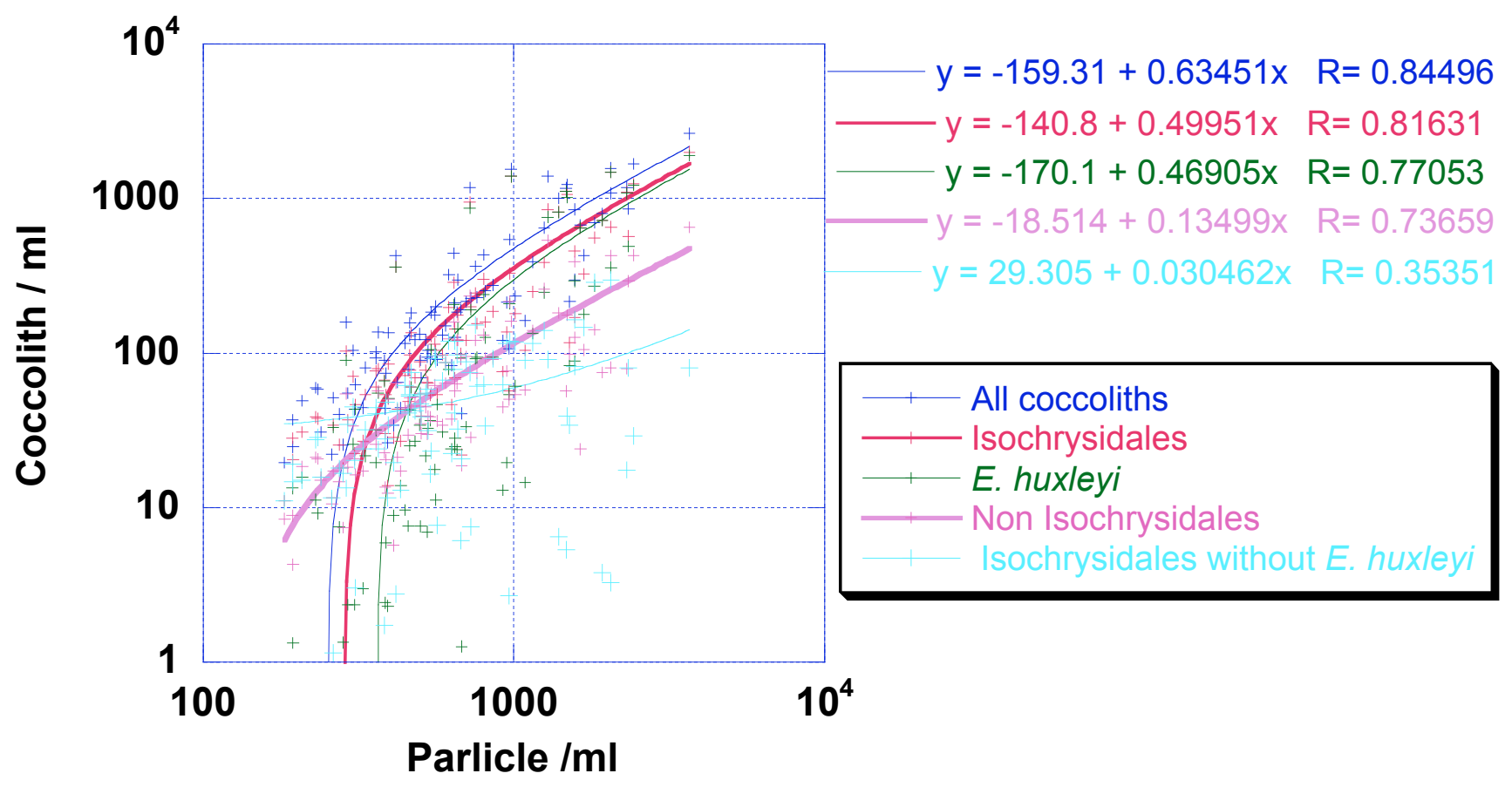

Fig. 7. Correlation between concentrations of suspended calcite particles and detached coccoliths of all coccolithophores taxa (deep blue), all Isochrysidales species (red), E. huxleyi (green), non-Isochrysidales coccolithophores taxa (purple), non-E. huxleyi Isochrysidales species (light blue). These numbers have been obtained by combining the concentration of Isochrysidales coccolith data (Fig. 5c) with the percentage of the different taxa estimated from coccosphere count shown in Fig. 4.

coccolithophore stocks estimated in this study are in the same range as previously reported for the more productive tropical Pacific, 1-240 cell $\mathrm{ml}^{-1}$ (Hagino and Okada, 2006), 060 cell ml${ }^{-1}$ (Balch and Kilpatrick, 1996), 1-100 cell ml ${ }^{-1}$ (Okada and Honjo, 1973; Ohkouchi et al., 1999), and 060 cell ml ${ }^{-1}$ (Giraudeau and Beaufort, 2007). The highest cell density of E. huxleyi $\left(240 \mathrm{cell} \mathrm{ml}^{-1}\right)$ in the South Equatorial Pacific was reported in the Peru Upwelling $\left(\sim 85^{\circ} \mathrm{W}-\right.$ $\sim 2^{\circ} \mathrm{S}$ ) (Hagino and Okada, 2006). This is equivalent to what was found in BIOSOPE, where up to $350 \mathrm{cell} \mathrm{ml}^{-1}$ were observed west of the PCU. The sample taken in the PCU on smaller membrane does not permit us to estimate the abundance of coccolithophores. One would nevertheless expect even higher abundance in this area because higher numbers of coccospheres of E. huxleyi are generally reported in the centre rather than outside of upwelling systems (Giraudeau and Bailley, 1995) where their abundance can reach several thousand of cell ml ${ }^{-1}$ (Mitchell-Innes and Winter, 1987).

\subsection{Deep production of marine Isochrysidales}

Coccolithophores are growing at the boundary of their greatest depth habitat in the South Pacific Gyre. For example at Station STB11, Florisphaera profunda was found between
200 and $300 \mathrm{~m}$. In the gyre, the maximum abundance of Isochrysidales occurred at about $120 \mathrm{~m}$, i.e., deeper than usually found for coccoliths in oligotrophic area (e.g. Okada and Honjo, 1973; Okada and McIntyre, 1979). The fact that coccolithophores calcify at depth greater than $100 \mathrm{~m}$ represents a significant change from the proposed high-light niche of $E$. huxleyi (e.g. Nanninga and Tyrrell, 1996) and the observed restriction of calcification to shallower waters than silicification (Poulton et al., 2006). A possibility is that these coccospheres were not living cells but the sinking remains of coccolithophores that grew at shallower depths. Several lines of evidence argue against this: 1) the maximum abundances of coccospheres coincide with the Deep Chlorophyll Maxima (DCM) 2) the production in the upper photic zone is too low to fuel the coccosphere higest number at the DCM which is 3 times larger than at the surface. This is particularly true for Florisphaera profunda, which is found only below $200 \mathrm{~m}$. 3 ) the community vertical structure is typical of oligotrophic area, 4) it is interesting to note that the DCM is not only the place of maximum abundance of Isochrysidales, but also an area in which they secrete heavier coccoliths and have larger cells. Why should a morphological change occur in dead assemblages during settling? 

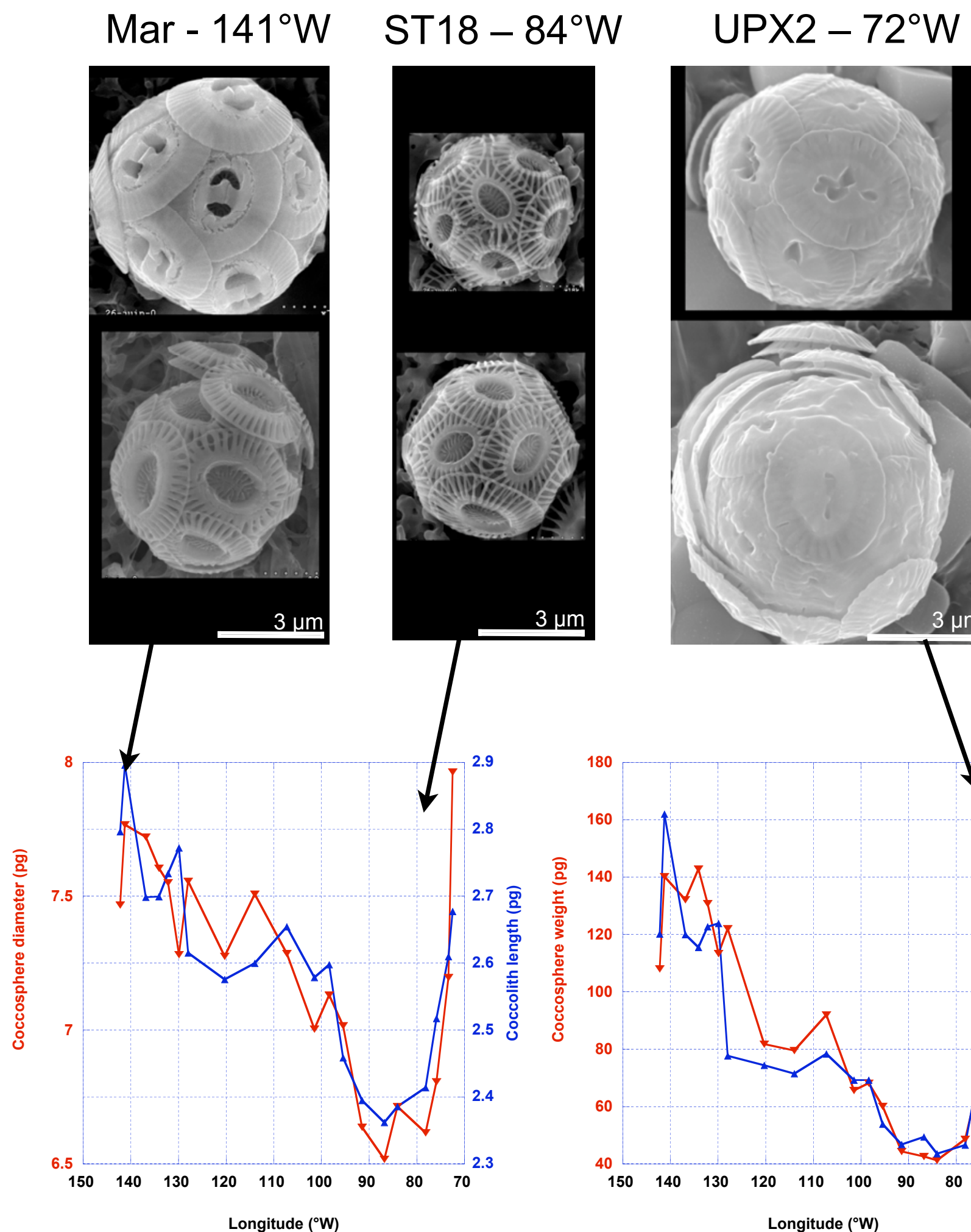

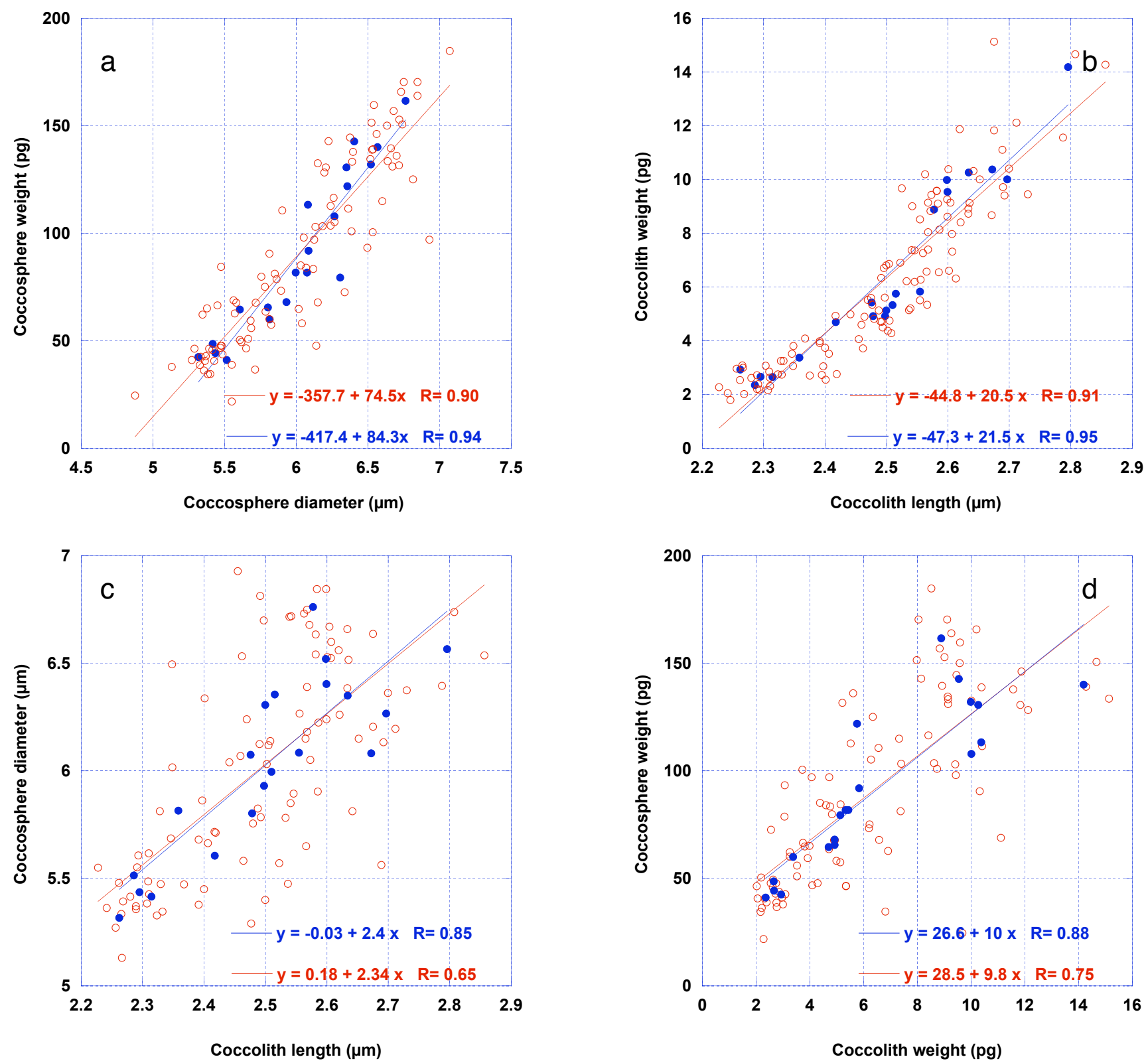

Fig. 9. Correlation between coccosphere diameter and weight (A), coccolith length and weight (B), coccolith length and coccosphere diameter $(\mathrm{C})$ weight of coccolith and coccosphere $(\mathbf{D})$ of Isochrysidales observed in BIOSOPE. Open red circles represent single BIOSOPE sample and the filled blue circles represent station average.

In conclusion, the system investigated can be considered as an endmember of oligotrophic systems with the deepest chlorophyll maximum and the clearest waters ever reported (Morel et al., 2007). The coccolithophores assemblage is typically adapted to these conditions with maximum cell density in general closely associated with the DCM. Furthermore it is very clear from pigment signature that below the chlorophyll maximum and up to depths of 250 and above, the dominant (sometimes the only) carotenoids is 19'hexnoyloxyfucoxanthin, the marker of prymnesiophyceae
(Ras et al., 2008, in their Fig. 11). This observation must be integrated with the layer of high backscattering ratio (the calcite marker) that is recorded at $\sim 240 \mathrm{~m}$ (Twardowski et al., 2007) at the GYR station. 


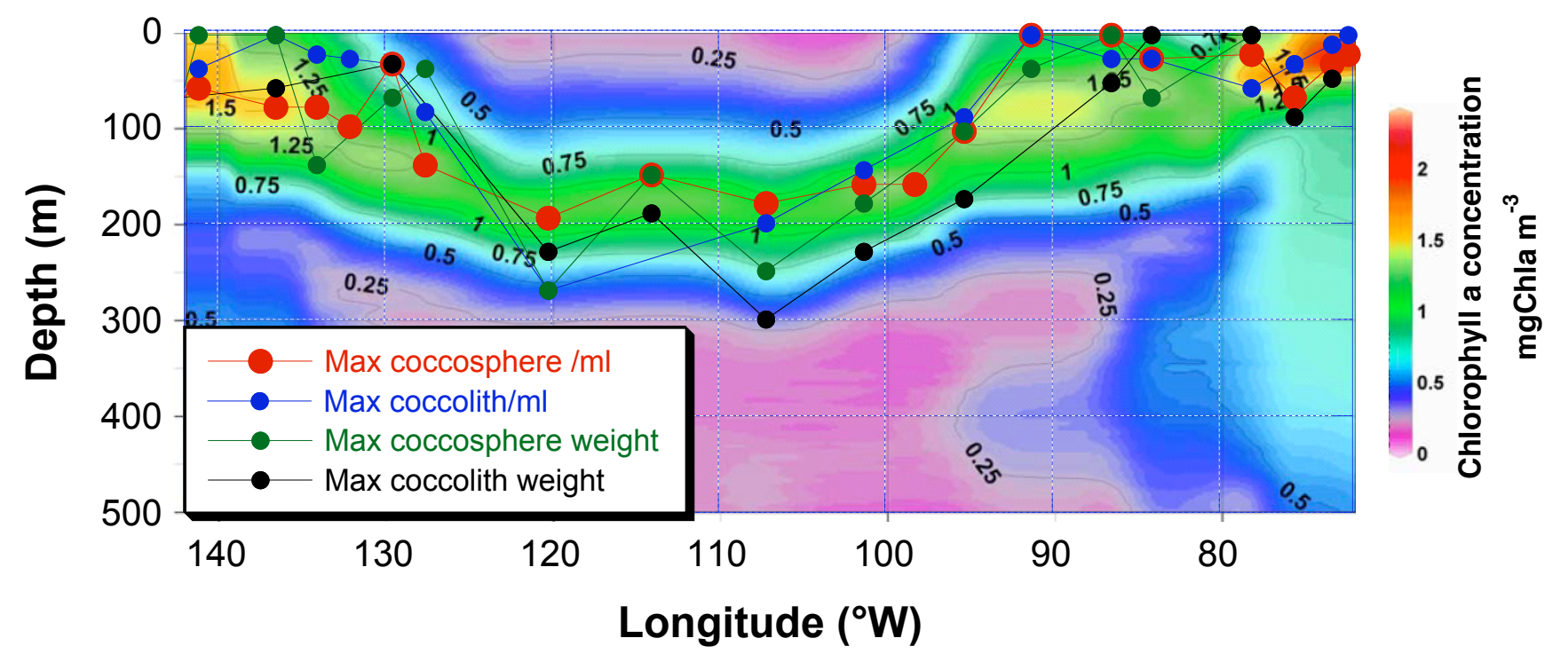

Fig. 10. Color section of the chlorophyll a concentration $\mathrm{mg} \mathrm{m}^{-3}$ along the BIOSOPE transect with the position in depth where the maximum value at a given Station is observed for the Isochrysidales coccosphere density (red), detached coccolith density (blue), weight of coccosphere (green), weight of coccoliths (black).

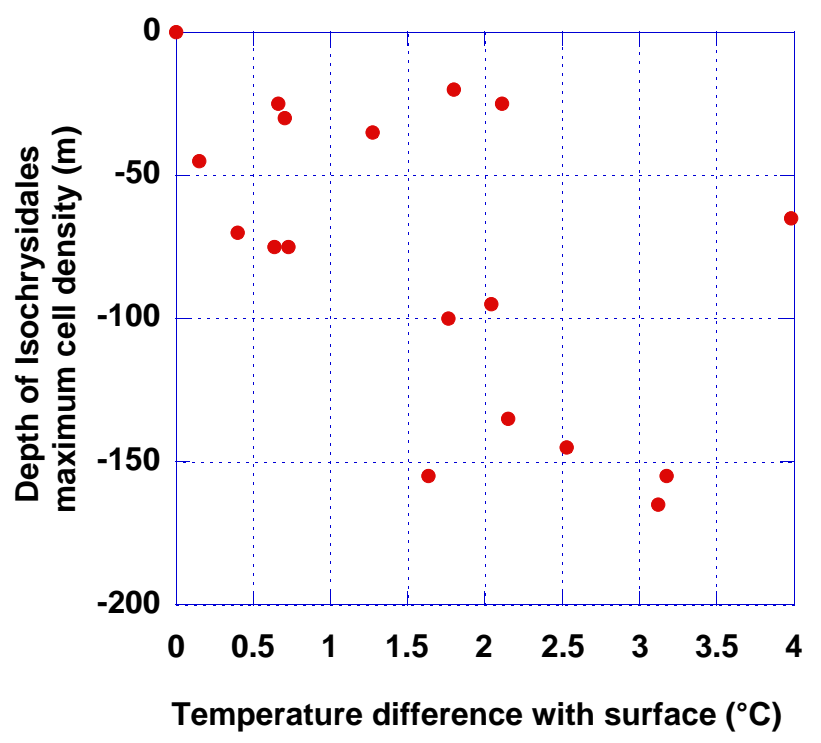

Fig. 11. Depth of Isochrysidales maximum density as a function of temperature difference between the depth of this maximum and surface.

\subsection{Implication of deep production for alkenone paleother-} mometry

When the temperature difference between the water surface and the depth of maximum abundance of the Isochrysidales, is calculated, it appears that for $1 / 3$ of the stations, the difference is greater than $2^{\circ} \mathrm{C}$ (Fig. 11). The Isochrysidales are the producers of alkenones used in paleoceanography as sea surface temperature (SST) proxy. Ohkouchi et al. (1999) described some discrepancies between SST estimates from North Pacific surface sediments and the observed SST at the same locations attributable to the fact that alkenones were produced in the DCM. Also, Conte et al. (2006) found some differences between the alkenone calibration curve based on surface sediments (Muller et al., 1998) and their calibration based on mixed-layer water measurements. But these differences were essentially recorded at high latitudes in absence of a DCM. Our results would indicate that it is may be excessive to infer SST from an alkenone record core taken below the South Pacific Gyre because alkenone would have been produced far below the surface (there are no suitable sediments to establish such a record in the Central Southern Pacific; Rea et al., 2006). But it has been shown that alkenones are produced exclusively in the mixed layer depth, and above the DCM in ALOHA Station in the oligotrophic North Pacific Gyre (Prahl et al., 2005). Either Station ALOHA is different from the South Pacific gyre (SPG) where E. huxleyi was abundant above DCM, or the secretion of alkenones by E. huxleyi is light dependent. In that case the deep production of Isochrysidales observed in SPG would not temper the SST reconstruction based on alkenones. 


\subsection{Emiliania huxleyi: important calcite producer}

The BIOSOPE PIC values are in the same range $(0.05-$ $0.35 \mathrm{mmol} \mathrm{m}^{-3}$ ) as previously reported for the Equatorial $\mathrm{Pa}$ cific (Balch and Kilpatrick, 1996) if we exclude one value from the latter study of $1.33 \mathrm{mmol} \mathrm{m}^{-3}$ in the open ocean upwelling. One important finding of the present study is a strong relation between the numbers of coccoliths of $E$. huxleyi and the number of suspended calcite particles (hence PIC) (Fig. 7). The "cloud" of highest abundance of coccolithophores (Fig. 5a,c) was dominated by E. huxleyi (Fig. 4); it also was the place of highest PIC and of significant enhancement of backscattering (Fig. 5g, i). Emiliania has been sometimes considered as one of the most important calcite producers (e.g. Westbroek et al., 1993); but it has been also suggested that it represents only an insignificant part of the oceanic calcite production (Paasche, 2002; Ziveri et al., 2007), because this species secreted one of the lightest coccoliths (Beaufort and Heussner, 1999; Young and Ziveri, 2000). The BIOSOPE transect covers the diversity of trophic conditions potentially observable in open ocean waters, we show that a large part of the fine calcite particles is attributable to Isochrysidales coccoliths. Calcification in the Tropical Pacific is very high, (similar the rate of photosynthesis) and the turnover times of calcite in the euphotic zone ranges from 3 to 10 days (Balch and Kilpatrick, 1996). These high turnover rates of calcite induce a high ballasting of organic matter by carbonate particles and a decrease of PIC possibly associated with a depletion of $\mathrm{Ca}^{++}$ion in the euphotic zone (Balch et al., 2007). Because of the high abundance of detached coccoliths and of coccospheres, the ballasting due to E. huxleyi coccoliths must have been particularly efficient around $90^{\circ} \mathrm{W}-30^{\circ} \mathrm{S}$. Ballasting could also have an effect on the alkalinity of the surface water. It is interesting to note that the area of highest standing stock of coccoliths present also has particularly low alkalinity. An inverse relation exists between alkalinity and PIC (Fig. 12), which is indicative of the effect of calcification on ocean surface alkalinity.

It is also interesting to note that the highest coccolith density was found in a scatter at depth greater than $30 \mathrm{~m}$, the depth limit of detection of coccoliths by satellite. Hitherto coccolith blooms detected by satellite are always in regions of shallow organic production (high latitudes, continental shelves, and upwelling zones) (Brown and Yoder, 1994; Balch et al., 2007), therefore, the calcite density of this scatter will be been largely underestimated, if ever detected, by satellite imagery.

4.5 Weight and size relation between coccolith and coccosphere

An interesting aspect of this study were the fact that there is a close relationship $(r=0.65)$ between the diameters of the Isochrysidales coccoliths and coccospheres (Fig. 8). A factor

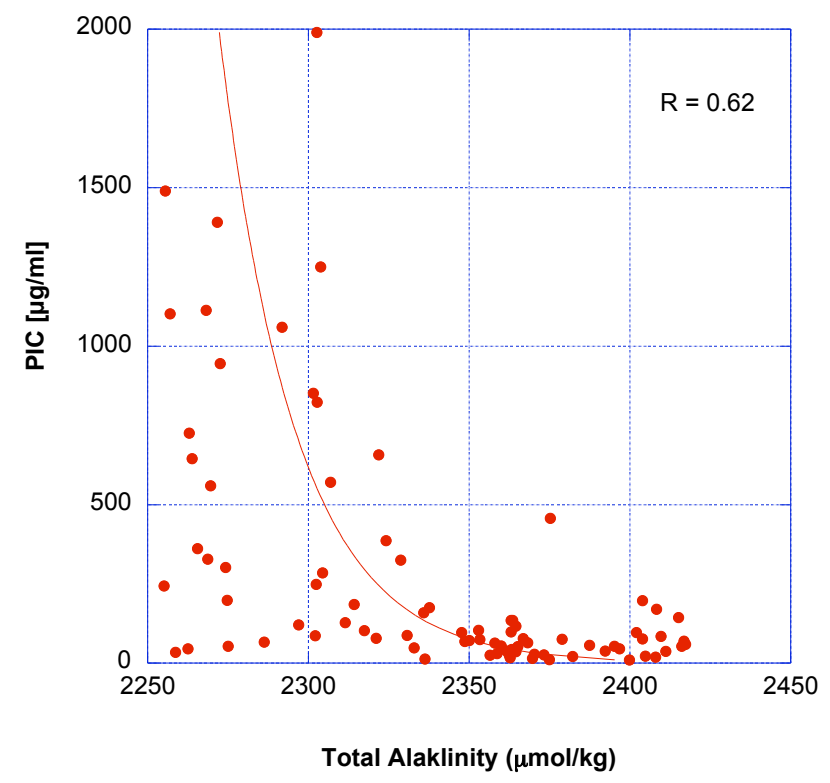

Fig. 12. Relation between the total weight of calcite particles and the total alkalinity.

of about $\sim 2.4$ (or $\sim 1.9$ taking into account the measurement bias for the coccolith length) can be used to estimate the diameter of a coccosphere from the length of a coccolith. Also the number of coccoliths per coccosphere is 15 on average without variations throughout the BIOSOPE transect. If the same relations were found elsewhere, these values would be useful in paleoceanographic studies for estimating the number and size of the cells of marine Isochrysidales from the number and length of their coccoliths.

\subsection{Calcification, cell diameter and carbonate chemistry}

The most calcified Isochrysidales are found in the high fertility zones of the Marquesas area and Peru-Chile Upwelling (PCU) (Figs. 5 and 8). Also we have shown that the maximal weight of both coccospheres and coccoliths are generally located in the DCM, which is close vicinity of the nitracline (Raimbault et al., 2008). These two observations may indicate that coccolithophores secrete more calcified coccoliths in higher fertility environments. This is in agreement with recent culturing and mesocosms experiments showing that E. huxleyi is more calcified in waters rich in $P$ and $N$ in batch cultures (Beaufort et al., 2007) or after addition of nutrients in mesocosms (Engel et al., 2005). However, these results contrast with those discussed in Paasche (2002). In BIOSOPE, the weights of the coccospheres and the coccoliths were weakly correlated with chlorophyll content and with stock of coccolith and coccosphere. Therefore other environmental factors than fertility or productivity might influence the calcification of coccolithophores. 
The lightest coccoliths and coccospheres were recorded between 80 and $95^{\circ} \mathrm{W}$, which is also exactly the place of the lowest alkalinity values in the upper $300 \mathrm{~m}$ of the BIOSOPE transect (Fig. 12). The concentration in carbonate ion was also particularly low in that area. These low values could be responsible, in part, for the low calcification of Isochrysidales cells. But this does not mean their growth was limited in such conditions because it is the place of highest concentrations of Isochrysidales coccoliths. In contrast, significant precipitation of calcite by E. huxleyi, revealed by highest PIC and coccolith concentrations, may have the effect of decreasing the dissolved carbonate concentration and the alkalinity of this area. Similarly, it has been recently suggested (Balch et al., 2007) that high PIC turnover such as recorded in the tropical Pacific, induces a depletion of calcium ion in the photic zone as a response of losses of PIC ballasted particles. We found a significant $(R=0.62)$ reverse logarithmic correlation between the concentration of coccoliths and alkalinity. Significant linear positive correlation exists between alkalinity and the weight of coccolith and coccospheres $(R=0.84$ and $R=0.85$ respectively on the station averages or $R=0.59$ and $R=0.74$ respectively on all samples) (Fig. $13 \mathrm{c}$ and i). This highlights the likely fundamental importance of alkalinity on calcification. Except in the 3 upwelling stations, carbonate concentration and calcite saturation state appears to also share a strong influence on the coccolith and coccosphere weights (Fig. 13a, b, g and h). The partial pressure of $\mathrm{CO}_{2}$ as well as $\mathrm{pH}$ does not appear to have significant impact on the degree of calcification of coccospheres and coccoliths $(R<0.03)$ (Fig. 13d, e, j and k). This could be see as contradicting with previous findings from culture and mesocosms experiments that predict a decrease of calcite production with increasing concentration of $\mathrm{CO}_{2}$ (Riebesell et al., 2000; Engel et al., 2005). Recent culture experiments show that an increase of $\mathrm{CO}_{2}$ may have a positive effect on calcification of E. huxleyi (Iglesias-Rodriguez et al., 2008) and other species (Langer et al., 2006). These experiments involve not only changes in $\mathrm{CO}_{2}$ and $\mathrm{pH}$, but also carbonate chemistry in very different ways depending on how the experiment was conducted. Our findings stress the importance of the entire carbonate system in the calcification of Isochrysidales.

The strong dependence of the concentration of carbonate ion on the coccolithophore calcification, has been recently illustrated by comparing Baltic and Black seas: the absence of coccoliths of $E$. huxleyi in the Baltic Sea result from low carbonate saturation states particularly during the winter (Tyrrell et al., 2008). In a comparison of numerical simulation and observed data from seasonal blooms in the Bering Sea, it has been shown that E. huxleyi production benefits greatly from an increase in the concentration of carbonate ion in the surface water resulting from the increase in phytoplankton production (Merico et al., 2006). These authors hypothesized that in a zone of seasonal blooms, E. huxleyi would calcify more after a spring bloom in response to the increase in carbonate ion concentration. This hypothesis may explain why the heaviest coccospheres were observed in the eutrophic and mesotrophic areas of the BIOSOPE experiment. The least calcified Isochrysidales were found at the subtropical front in the highest coccosphere abundance zone of the BIOSOPE experiment. Because it is not a highly productive area, the production of coccoliths may have decreased the carbonate ion concentration, making calcification more difficult for E. huxleyi.

Multiple regression, applied to the weight of coccoliths or coccospheres with seven environmental parameters (total alkalinity, concentration of $\mathrm{O}_{2}, \mathrm{CO}_{3}$, and $\mathrm{OH}$, temperature, salinity, and saturation of calcite $(\Omega \mathrm{Ca}))$, shows high correlations: $R=0.97(0.75)$ and $0.97(0.82)$ respectively for the station averages (all samples) (Fig. 13f and 1). The fact that the correlations are relatively less significant for the entire sample set than for the station average results not only from noise but also from the fact that at every station the maximum calcification was found at the maximum of coccolithophore density in the DCM (Fig. 10 and discussion above). Therefore the depth profiles of weight do not follow the carbonate chemistry profiles. The biotic (coccolithophores production) influence on calcification exist mainly at local scale (depth) whereas the abiotic (carbonate chemistry) plays a more important role at regional (horizontal) scale where $94 \%$ of the variability of coccolith and coccosphere weight can be explained by the change in these 7 independent variables. An important finding is that the degree of calcification of Isochrysidales strongly depends on environmental parameters. This relation was found at the "order" level rather than at the species level, suggesting that the specific composition of Isochrysidales could be related to carbon chemistry of the water. For example the fact that $G$. oceanica dominates around the Marqueasas area could be related to the higher alkalinity of this area that presents an advantage for this relatively highly calcified species.

\section{Conclusions}

In most of the BIOSOPE stations the coccolithophore standing stocks were low, except in the vicinity of Peru Chile Upwelling system $\left(80\right.$ to $\left.100^{\circ} \mathrm{W}\right)$, where the Isochrysidales were highly abundant at mid photic zone depth (up to 350000 coccospheres per liter between 30 and $60 \mathrm{~m}$ ). This low abundance has been also reported in other studies conducted in the Tropical Pacific. In the South Pacific Gyre coccolithophores are rare at the surface but grow over the entire 0-300 m water column. The Isochrysidales coccoliths compose a significant fraction of PIC. The area of highest coccolithophore standing stock ( 80 to $100^{\circ} \mathrm{W}$ ) here corresponds to the place of lowest alkalinity. There is a close relationship between the diameter of the coccoliths and length of the coccospheres of Isochrysidales. The most calcified Isochrysidales were found in the Marquesas area and in the Peru-Chile Upwelling (PCU) and the least calcified were found west of 

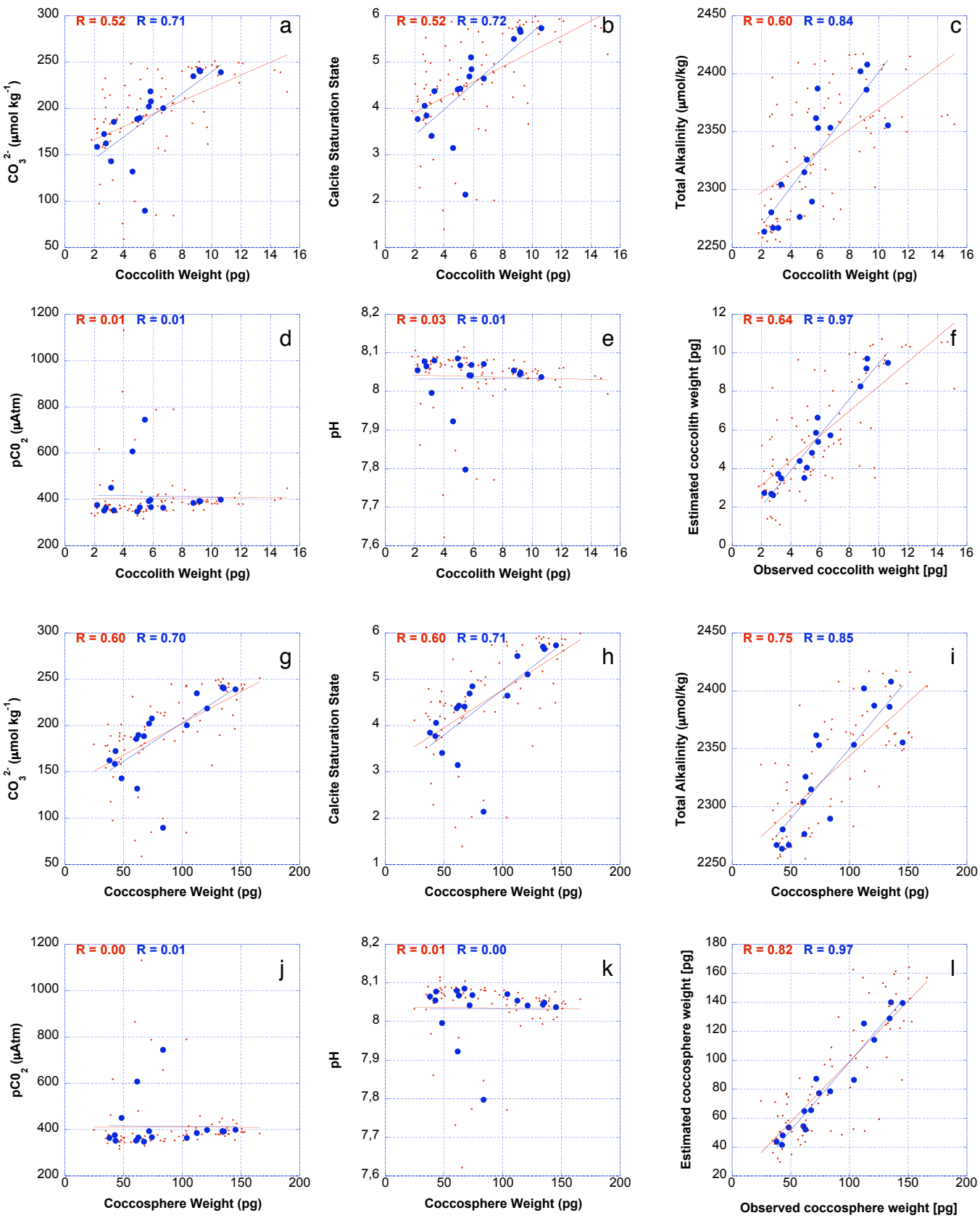

Fig. 13. Correlations between carbonate ion concentration $(\mathbf{a}, \mathbf{g})$, calcite saturation state $(\mathbf{b}, \mathbf{h})$ alkalinity $(\mathbf{c}, \mathbf{i}) \mathrm{pCO} 2(\mathbf{d}, \mathbf{j})$, $\mathrm{pH}(\mathbf{e}, \mathbf{k})$ and the weight of Isochrysidales coccoliths (a, b, c, d, e) and coccospheres ( $g, h, I, j, k)$, and between observed and estimated weight of Isochrysidales coccoliths (f) and coccospheres (l). The entire suite of sample is represented in red, and the Station averages are represented in blue. The weights were estimated with the following equations:

Coccolith weight $=3.265+(0.075 \cdot$ Alkalinity $)-\left(0.040 \cdot\left[\mathrm{O}_{2}\right]\right)-(0.380 \cdot$ Temperature $)-(4.557 \cdot$ Salinity $)+\left(0.207 \cdot\left[\mathrm{CO}_{3}\right]\right)$

$-10.178 . \Omega \mathrm{Ca})+(2.268 \cdot[\mathrm{OH}])$

Coccosphere weight $=-1001.222+(1.980 \cdot$ Alkalinity $)+\left(0.078 \cdot\left[\mathrm{O}_{2}\right]\right)+(4.448 \cdot$ Temperature $)-(102.652 \cdot$ Salinity $)$

$-\left(0.952 \cdot\left[\mathrm{CO}_{3}\right]\right)-(31.654 . \Omega \mathrm{Ca})+(4.864 \cdot[\mathrm{OH}])$.

Those equations have been obtained by performing multiple regressions between these parameters and coccospheres and coccolith weight with the Station averages. 
the PCU where the abundance of coccosphere is highest. The regional variability in the degree of calcification of Isochrysidales (weight of their coccoliths and coccospheres) strongly depends on environmental parameters (essentially the carbonate chemistry and the temperature). In area of high alkalinity the Isochrysidales secretes the heaviest coccospheres. The weight of Isochrysidales' coccoliths and coccospheres can be predicted at $94 \%$ from a set of 7 abiotic components.

Coccolithophores occur at great depths in the South Pacific Gyre: the maximum abundances of Isochrysidales were found between 150 and $170 \mathrm{~m}$. The Deep Chlorophyll maximum is not only the place of maximum abundance of Isochrysidales, but also an area in which they secrete heavier coccoliths and have larger cells. Given the spatial extension of subtropical gyres, the role of coccolithophore in mediating particulate flux in these extreme oligotrophic waters may be significant when dealing with global ocean estimates.

Acknowledgements. Dominique Tailliez and Claudie Bournot are warmly thanked for their efficient help in CTD rosette management and data processing. We are thankful to Daniel Vaulot, Manon Viprey, and Laurence Garczarek for having filtered water samples for coccoliths during BIOSOPE cruise. We are thankful to Marie-Pierre Aubry and Amos Winter who made interesting comments on an earlier version of this paper. This is a contribution of the BIOSOPE project of the LEFE-CYBER program. BIOSOPE cruise was funded by the Centre National de la Recherche Scientifique (CNRS), the Institut des Sciences de l'Univers (INSU), the Centre National d'Etudes Spatiales (CNES), the European Space Agency (ESA), The National Aeronautics and Space Administration (NASA) and the Natural Sciences and Engineering Research Council of Canada (NSERC). This work is part of the pluridisciplinary project BOOM - Biodiversity of Open Ocean Microcalcifiers, funded by the "Institut Français de la Biodiversité" via the "Agence National de la Recherche", grant ANR-05-BDIV-004.

Edited by: J. Middelburg

\section{References}

Archer, D., Winguth, A., Lea, D., and Mahowald, N.: What caused the glacial/interglacial atmospheric $\mathrm{pCO}_{2}$ cycles, Rev. Geophys., 38, 159-189, 2000.

Azouzi, L., Goncalves Ito, R., Touratier, F., and Goyet, C.: Anthropogenic carbon in the Eastern South Pacific Ocean, Biogeosciences Discussions, 4, 1815-1837, 2007.

Balch, W. M. and Kilpatrick, K.: Calcification rates in the equatorial pacific along 140 W, Deep Sea Res. II, 43, 971-993, 1996.

Balch, W. M., Drapeau, D. T., Bowler, B. C., and Booth, E. S.: Prediction of pelagic calcification rates using satellite measurements, Deep Sea Res. II, 54, 478-495, 2007.

Beaufort, L. and Heussner, S.: Coccolithophorids on the continental slope of the bay of biscay, 1. Production, transport and contribution to mass fluxes, Deep Sea Research II, 46, 2147-2174, 1999.

Beaufort, L. and Dollfus, D.: Automatic recognition of coccolith by dynamical neural network, Mar. Micropaleont., 51(1-2), 57-73, 2004.
Beaufort, L.: Weight estimates of coccoliths using the optical properties (birefringence) of calcite, Micropaleontol., 51, 289-298, 2005.

Beaufort, L., Probert, I., and Buchet, N.: Effects of acidification and primary production on coccolith weight: Implications for carbonate transfer from the surface to the deep ocean, Geochemistry Geophysics Geosystems, 8, Q08011, doi:210.1029/2006GC001493, 2007.

Brown, C. W. and Yoder, J. A.: Coccolithophorid blooms in the global ocean., J. Geophys. Res., 99(C4), 7467-7482, 1994.

Claustre, H. and Maritorena, S.: The many shades of ocean blue, Science, 302, 1514-1515, 2003.

Claustre, H., Sciandra, A., and Vaulot, D.: Introduction to the special section bio-optical and biogeochemical conditions in the South East Pacific in late 2004: the BIOSOPE program, Biogeosciences, 5, 679-691, 2008, http://www.biogeosciences.net/5/679/2008/.

Claustre, H., Huot, Y., Obernosterer, I., Gentili, B., Tailliez, D., and Lewis, M.: Gross community production and metabolic balance in the South Pacific Gyre, using a non intrusive bio-optical method, Biogeosciences, 5, 463-474, 2008, http://www.biogeosciences.net/5/463/2008/.

Conte, M. H., Sicre, M. A., Ruhlemann, C., Weber, J. C., Schulte, S., Schulz-Bull, D., and Blanz, T.: Global temperature calibration of the alkenone unsaturation index (uk'37) in surface waters and comparison with surface sediments, Geochem. Geophys. Geosystems, 7, Q02005, doi:02010.01029/02005GC001054, 2006.

de Vargas, C., Aubry, M. P., Probert, I., and Young, J.: Origin and evolution of coccolithophores: From coastal hunters to oceanic farmers, in: Evolution of aquatic photoautotrophs, edited by: Falkowski, P. G., and Knoll, A. H., Academic Press, New York, 456 pp., 2007.

Dollfus, D. and Beaufort, L.: Fat neural network for recognition of position-normalised objects, Neural Networks, 12, 553-560, 1999.

Engel, A., Zondervan, I., Aerts, K., Beaufort, L., Benthien, A., Chou, L., Delille, D., Gattuso, J. P., Harlay, J., Heemann, C., Hoffmann, L., Jacquet, S., Nejstgaard, J., Pizay, M. D., RochelleNewall, E., Schneider, U., Terbrueggen, A., and Riebesell, U.: Testing the direct effect of $\mathrm{CO}_{2}$ concentration on a bloom of the coccolithophorid Emiliania huxleyi in mesocosm experiments, Limnol. Oceanogr., 50, 493-507, 2005.

Feely, R. A., Sabine, C. L., Lee, K., Berelson, W., Kleypas, J., Fabry, V. J., and Millero, F. J.: Impact of anthropogenic $\mathrm{CO}_{2}$ on the $\mathrm{CaCO}_{3}$ system in the oceans, Science, 305, 362-366, 2004.

Giraudeau, J. and Bailley, G. W.: Spatial dynamics of coccolithophore communities during an upwelling event in the southern Benguela system, Continent. Shelf. Res., 15, 1825-1852, 1995.

Giraudeau, J. and Beaufort, L.: Coccolithophores from extant population to fossil assemblages, in: Developments in marine geology, proxies in late Cenozoic paleoceanography edited by: Hilaire-Marcel, C. and de Vernal, A., Elsevier, Amsterdam, 409439, 2007.

Hagino, K. and Okada, H.: Intra- and infra-specific morphological variation in selected coccolithophore species in the Equatorial and Subequatorial Pacific Ocean, Mar. Micropaleont., 58, 184 206, 2006. 
Iglesias-Rodriguez, M. D., Halloran, P. R., Rickaby, R. E. M., Hall, I. R., Colmenero-Hidalgo, E., Gittins, J. R., Green, D. R. H., Tyrrell, T., Gibbs, S. J., von Dassow, P., Rehm, E., Armbrust, E. V., and Boessenkool, K. P.: Phytoplankton calcification in a high$\mathrm{CO}_{2}$ world, Science, 336-340, doi:10.1126/science.1154122, 2008.

Langer, G., M. , Geisen, Baumann, K.-H., Kläs, J., Riebesell, U., Thoms, S., and Young, J. R.: Species-specific responses of calcifying algae to changing seawater carbonate chemistry, Geochemistry, Geophysics, Geosystems, 7, Q09006, doi:10.1029/02005GC001227, 2006.

Longhurst, A.: Ecological geography of the sea, Academic Press, San Diego, 398 pp., 1998.

Merico, A., Tyrrell, T. and Cokacar, T.: Is there any relationship between phytoplankton seasonal dynamics and the carbonate system?, J. Mar. Syst., 59, 120-142, 2006.

Milliman, J. D.: Production and accumulation of calcium carbonate in the ocean - budget of a nonsteady state, Global Biogeochem. Cycles, 7, 927-957, 1993.

Mitchell-Innes, B. A. and Winter, A.: Coccolithophores : A major phytoplankton component in mature upwelled waters off thje cape peninsula, south africa in march, 1983, Mar. Biol., 95, 2530, 1987.

Morel, A., Gentili, B., Claustre, H., Babin, M., Bricaud, A., Ras, J., and Tieche, F., , : Optical properties of the "Clearest" Natural waters, Limnol. Oceanogr., 52, 217-229, 2007.

Muller, P. J., Kirst, G., Ruhland, G., von Storch, I., and RosselMele, A.: Calibration of the alkenone paleotemperature index uk'37 based on core-top from the Eastern South Atlantic and the global ocean $\left(60^{\circ} \mathrm{N}-60^{\circ} \mathrm{S}\right)$, Geochim. Cosmochim. Acta,, 62, 1757-1722, 1998.

Nanninga, H. J. and Tyrrell, T.: Importance of light for the formation of algal blooms by Emiliania huxleyi, Mar. Ecol. Prog. Ser., 136, 195-203, 1996.

Ohkouchi, N., Kawamura, K., Kawahata, H., and Okada, H.: Depth ranges of alkenone production in the Central Pacific Ocean, Global Biogeochem. Cycles, 13, 695-704, 1999.

Okada, H. and Honjo, S.: The distribution of oceanic coccolithophorids in the Pacific, Deep Sea Res., 20, 355-374, 1973.

Okada, H. and McIntyre, A.: Modern coccolithophores of the Pacific and North Atlantic oceans, Micropaleontol., 23, 1-55, 1979.

Orr, J. C., Fabry, V. J., Aumont, O., Bopp, L., Doney, S. C., Felly, R. A., Gananadesikan, A., Gruber, N., Ishida, A., Joos, F., Key, R., Lindsay, K., Maier-Reimer, E., Matear, R., Monfray, P., Mouchet, A., Najjar, R., Plattner, G.-K., Rodgers, K. B., Sabine, C. L., Sarmiento, J. L., Schlitzer, R., Slater, R. D., Totterdell, I. J., Weirig, M. F., Yamanaka, Y., and Yool, A.: Anthropogenic ocean acidification over the twenty-first century and its impact on calcifying organisms, Nature, 437, 681-687, 2005.
Paasche, E.: A review of the coccolithophorid Emiliania huxleyi (Prymnesiophyceae), with particular reference to growth, coccolith formation, and calcification-photosynthesis interactions., Phycologia, 40, 503-529, 2002.

Poulton, A. J., Sanders, R., Holligan, P. M., Stinchcombe, M. C., Adey, T. R., Brown, L., and Chamberlain, K.: Phytoplankton mineralization in the Tropical and Subtropical Atlantic Ocean, Global Biogeochem. Cycles, 20, GB4002, doi:10.1029/2006GB002712, 2006.

Prahl, F. G., Popp, B. N., Karl, D. M., and Sparrow, M. A.: Ecology and biogeochemistry of alkenone production at Station ALOHA, Deep Sea Res., 52, 699-719, 2005.

Raimbault, P., Garcia, N., and Cerutti, F.: Distribution of inorganic and organic nutrients in the South Pacific Ocean - evidence for long-term accumulation of organic matter in nitrogen-depleted waters, Biogeosciences, 5, 281-229, 2008, http://www.biogeosciences.net/5/281/2008/.

Ras, J., Claustre, H., and Uitz, J.: Spatial variability of phytoplankton pigment distribution in the South East Pacific, Biogeoscience, 5, 353-369, 2008.

Rea, D., Lyle, M. W., Liberty, L. M., Hovan, S. A., Bolyn, M. P., Gleason, J. D., Hendy, I. L., Latimer, J. C., Murphy, B. M., Owen, R. M., Paul, C. F., Rea, T. H. C., Stancin, A. M., and Thomas, D. J.: Broad region of no sediment in the Southwest Pacific Basin, Geology, 34, 873-876, 2006.

Riebesell, U., Zondervan, I., Rost, B., Tortell, P. D., Zeebe, R., and M., M. F. M.: Reduced calcification of marine plankton in response to increased atmospheric $\mathrm{CO}_{2}$, Nature, 407, 364-367, 2000.

Twardowski, M. S., Claustre, H., Freeman, S. A., Stramski, D., and Huot, Y.: Optical backscattering properties of the "clearest" natural waters, Biogeoscience, 4, 1041-1058, 2007.

Tyrrell, T., Schneider, B., Charalampopoulou, A., and Riebesell, U.: Coccolithophores and calcite saturation state in the Baltic and Black seas, Biogeosciences, 5, 485-494, 2008, http://www.biogeosciences.net/5/485/2008/.

Westbroek, P., Brown, C. W., Bleijswijk, J. v., Brownlee, C., Brummer, G. J., Conte, M., Egge, J., Fernandez, E., Jordan, R., Knappertsbusch, M., Stefels, J., Veldhuis, M., Wal, P. V. D., and Young, J.: A model system approach to biological climate forcing. The example of Emiliania huxleyi, Global and Planetary Change, 8, 27-46, 1993.

Winter, A., Jordan, R. W., and Roth, P. H.: Biogeography of living Coccolithophores in oceanic waters, in: Coccolithophores, edited by: Winter, A. and Siesser, W. G., Cambridge University Press, Cambridge, 161-177, 1994.

Young, J., and Ziveri, P.: Calculation of coccolith volume and its use in calibration of carbonate flux estimates, Deep Sea Res., 47, 1679-1700, 2000.

Ziveri, P., de Bernardi, B., Baumann, K.-H., Stoll, H. M., and Mortyn, G. P.: Sinking of coccolith carbonate and potential contribution to organic carbon ballasting in the deep ocean, Deep Sea Research Part II: Topical Studies in Oceanography, 54, 659-675, 2007. 